\title{
Impact of Microfinance on Entrepreneurial Development: The Case of Egypt
}

\author{
Hala Helmi El Hadidi \\ Associate Professor \\ Business Department \\ Faculty of Business, Political Science and Economics \\ British University in Egypt
}

\begin{abstract}
This research investigates the impact of microfinance on entrepreneurial development of small scale enterprises that are aiming for growth and development in Egypt. The research used questionnaire as an instrument of primary data collection. Tables and simple percentages were used in data presentation. The study centers on two broad variables; the dependent variable which is entrepreneurial development and the independent variable which is microfinance institutions. Three different hypotheses were formulated and tested using various statistical tools such as chi-square test, analysis of variance and simple regression analysis. The study reveals that (i) there is a significant difference in the number of entrepreneurs who used microfinance institutions and those who do not use them; (ii) there is a significant effect of microfinance institutions activities in predicting entrepreneurial productivity; and (iii) that there is no significant effect of microfinance institutions activities in predicting entrepreneurial development. The research concludes that microfinance institutions over the world and especially in Egypt are identified to be one of the key players in the financial industry that have positively affected individuals, business organizations, other financial institutions, the government and the economy at large through the services they offer and the functions they perform in the economy.
\end{abstract}

Keywords: Microfinance; Entrepreneurial Development; Egypt, Entrepreneurship; Small and Medium-Scale Enterprises.

\section{Introduction}

The issue of sustainable development in the Third World countries like Egypt has been a growing concern to both the government and the private sector. The huge amounts of money the government has been investing on this platform over the years have not yielded any meaningful result. Poverty is a characteristic of Egyptian households/ individuals. It has been realized in recent years that there are limits to which government can singly promote development. Most of the traditional functions being carried out by the government in most countries ranging from the provision of economic development are becoming increasingly difficult to accomplish. Egypt as a nation has its own peculiar developmental challenges because of maladministration, corruption, infrastructural decay, insecurity of lives and properties, unstable macroeconomic regime and unpredictable fiscal policies by successive administrations (Fasua, 2014). Thus, both the public and the private sectors of the economy and every segment of the society need to be involved in the industrial development process of the country. It is on this basis that government begins to engage in privatization policy with the view of allowing the private sector to participate in the economic development of the nation. Consequently, various governments of the nation begin to find pathways to involve the private sector in the developmental process of their country's economy.

One of the responses to the challenges of development in the developing countries is the encouragement of entrepreneurial development scheme. Egypt had even taken more robust step by including entrepreneurial studies in the academic curriculum of its educational system. The believe of such policy makers is that such decision will instill entrepreneurial spirit in the mind of people so as to prepare them for wealth creation through small scale enterprises (Fasua, 2014). Small scale enterprise is very crucial to the development of a country's economy, especially countries like Egypt. Entrepreneurship is important to national development, poverty eradication and employment generation. It is the basis of any nation's industrialization. A number of studies have been carried out on the impact of microfinance on entrepreneurial development. In fact, academic interest that shows the impact of microfinance on entrepreneurial development is evidenced by the fact that some academic journals have devoted special issues to research establishing this linkage. 
Some scholars focused on the mechanism by which poverty is reduced. Amin, Rai, and Topa (2010) focus their article on the ability of microfinance to reach the poor and vulnerable. They focus their article in such a manner because of concerns that microfinance is only serving people slightly below or above the line of poverty, however the really poor and destitute are being systematically excluded. By contrast, Copestake, Halotra and Johnson (2010) analyze the impact of microfinance on firms and individual wellbeing. Copestake et al (2010) focus on business performance and household income to establish a link between the availability of microfinance and overall wellbeing of the poor. Evans and Adams (2009) approach the microfinance question at a slightly different angle. However, the above mentioned authors seek to explain non participation in the microfinance evolution, stating that while microfinance is used as a viable tool in fighting poverty, more than $75 \%$ of the poor individuals choose not to participate for various reasons. Ryne and Holt (2000) provide a meta-analysis of microfinance and focus on women empowerment, intending to show while various studies conflict in their conclusions as to the impact of microfinance on women empowerment. Park (2001) evaluates the actual microfinance programs in China using 3 key measures (targeting, sustainability and overall impact). Thus, both research and practice have seen an increasing concern about the impact of microfinance. In spite of this emphasis, current research did not provide sufficient justification for the link between microfinance and entrepreneurial development in developing countries.

Besides, the empirical evidence emerging from various studies about the effect of microfinance on entrepreneurial development have so far yielded mixed results that are inconclusive and contradictory. Thus, the question of whether microfinance improves or worsens entrepreneurial development is still worthy of further research. In addition, the impact of microfinance on entrepreneurial development has not received adequate research attention in Egypt. Research also shows most of the studies on impact of microfinance on entrepreneurial development that have been reported were carried out on industrialized countries. This means that there is a major gap in the relevant literature on developing countries including Egypt, which has to be covered by research. This research attempts to fill this gap by studying the situation in Egypt and providing more empirical evidence on the effects of microfinance on entrepreneurial development.

The importance of microfinance to entrepreneurial development made the Central Bank of Egypt adopted it as the main source of financing entrepreneurship in Egypt. Despite this, however, finance is still considered as one of the major hindrances to entrepreneurial development in Egypt (Ledgerwood, 2011). While government and NonGovernment Organisations (NGOs) have been engaging a number of programmes and policies to encourage entrepreneurship in the country, Egypt is still on the list of the poorest countries in the world with unemployment level rising alarmingly. It is therefore necessary at this junction to undertake an assessment of the extent to which microfinance can impact entrepreneurial development in Egypt.

That is the overall objective of this paper. The specific objectives are to: (i) examine the importance of entrepreneurial activities to the sustainable development of Egypt; (ii) examine the challenges of accessibility to capital for the development of entrepreneurship in Egypt; (iii) examine the impact of microfinance institutions on entrepreneurial development; and (iv)create the awareness of the importance of microfinance institutions to entrepreneurship development in Egypt. In other to achieve the above stated objectives, the following research questions are advanced: (i) Does microfinance contribute to entrepreneurial activities that can lead to sustainable development in Egypt? (ii) Do entrepreneurs have access to capital for the development of small and medium Size entrepreneurship in Egypt? (iii) What are the prospects of microfinance in the development of entrepreneurship in Egypt? Does entrepreneurial development have any implication on the industrial development of Egypt?

The following null hypotheses are proposed and tested in the course of this study. (i) There is no significant difference between entrepreneurs who use microfinance and those who do not. (ii) There is no significant effect of microfinance institutions activities in predicting entrepreneurial productivity. (iii) There is no significant effect of microfinance institutions activities in predicting entrepreneurial development.

\section{Literature review}

\section{Egyptian Business Environment}

Microfinance is not a new concept. Small micro-credit services have been provided since the 1700s but in Egypt it was not until the 1950s that agricultural micro-lending was made available through the government-owned bank, Principal Bank for Development and Agriculture (PBDAC). 
Since then, numerous other initiatives have been introduced such as the Productive Families project (PF), which was initiated by the Ministry of Social Affairs in 1977 to provide microcredit to low-income families, conditional on having a government employee guarantor. In 1982, the United Nations Children's Fund (UNICEF) launched a programme for rural women with a focus on female-headed households. The programme was implemented by the Ministry of Social Affairs while the Ford Foundation funded the Association for Garbage Collectors in Cairo in 1983 to provide credit and employment-related training (Barsoum, 2013). The project now operates under the auspices of the Ministry of Rural Development.

The field of microfinance in Egypt dramatically changed in the late 1980s. In 1988 an initiative by the United States Agency for International Development (USAID) in Egypt geared such changes (USAID, 2013). USAID funds were earmarked for the development of the small and micro-enterprise sector. The fund was directed toward seed capital, institutional development financing, training and technical assistance, and research (USAID 2013). USAID designed two models for the delivery of credit in Egypt: the foundation model and the bank model. The foundation model was to establish not-for-profit foundations to serve as intermediaries between individual borrowers and the lending banks where seed funds were deposited as a guarantee of a credit line for these borrowers (USAID, 2013). Two foundations were first established: the Small Enterprise Development Foundation (Cairo Foundation, which provides credit in the Cairo governorate) and the Alexandria Small Business Association (ABA). The model was later replicated in five other governorates: Port Said (1995), Assuit (1996), Sharkyla (1997), Dakahleya (1998), and Kafr El-Sheikh (1999). The bank model was implemented by the National Bank for Development with staff in 13 of its branches dedicated to the provision of small and microenterprise lending and mobile units radiating out of each branch (USAID 2013).

While expanding the field significantly, the USAID contribution initiated a new stream in the microfinance field in Egypt that distinguished it from the earlier experience. It emphasized the business enhancement model vis-a-vis the earlier poverty alleviation model. Different methodologies and targeting mechanisms emerged. The new target group was small businesses in urban locations instead of the earlier emphasis on rural home-based activities. The clientele of the new initiative was largely male despite the donors' emphasis on a female presence. Loan sizes were relatively large. More emphasis was placed on program self-sufficiency, sustainability, and even profitability (USAID, 2013) as opposed to the earlier reliance on donor funds. In their targeting schemes, programs emphasized the economic potential of the borrower rather than their poverty. Extension officers were predominantly male and a strict bonus and salary system was implemented in order to tie the repayment rate of the borrowers to the income of the extension officer who chose them and was responsible for the collection of their loan installments. This wage system constituted a vital mechanism that ensured that only prospering businesses received credit and that volatile or low-income economic activities were filtered out.

Established in 1991, the Social Fund for Development (SFD) is currently the largest donor program in the field of small and micro-enterprise lending in Egypt. SFD functions as a governmental organization that was initiated specifically to mitigate the negative impact of structural adjustment policies and acts as an intermediary between international donors and local constituencies. More than $70 \%$ of the budget of the Fund for Phase 2 dated (19972000) was allocated for the two main programs providing credit at SFD: the Small Enterprise Development Organization (SEDO) and the Community Development Program (CDP) (Nader, 2016). These two programs neatly follow the distinction already existing in the field between the economic survival model and the business enhancement model.

SEDO targets unemployed youth and new graduates with relatively larger loans (35,000 Egyptian pounds) following the business enhancement growth model. In 2000, more than LE 2.3 billion was committed to support small enterprises (USAID, 2013). Most of the credit recipients are males in urban areas. Credit is provided through governmental and commercial banks and is subsidized at a differentiated interest rate structure depending on the loan size, the borrower's type of business, duration of the loan, and whether the loan is for a start-up or an existing business. The emphasis of these programs is on the informal sector and micro-entrepreneurs and the loan approval requirements of many of them include a work permit, economic activity licensing, social security registration, tax card, and commercial registry, which are documents unavailable among micro entrepreneurs working in the informal sector.

$\mathrm{CDP}$, on the other hand, provides revolving funds to grassroots organizations for the provision of microcredit for poverty alleviation and economic survival. 
These organizations include local and international NGOs, CDAs, branches of the PBDAC, and offices of the government. Priority is given to organizations operating in the poorer communities in Upper Egypt, Delta, and squatter urban settlements in Cairo. Following the economic survival model, CDP considers credit an element of an integrated package including primary health care, literacy, community schools, female empowerment, population and family planning, and environment (USAID, 2013).

Intermediary organizations are required to consider these aspects in designing their lending programs. Credit is provided on a group collateral basis at a low interest rate (7\%). In 1997, USAID renewed its support to the microfinance field in Egypt by starting a new agreement with the Credit Guarantee Corporation (CGC) to serve as an umbrella organization that provides technical and financial services to different implementing entities, from NGOs and CDAs. CGC was established in 1990 with funding from USAID and nine Egyptian financial institutions as a not-for-profit corporation in order to "assist in the delivery of credit to small businesses that lack sufficient collateral to obtain loans from banks" (USAID 2013).

Although the SFD and USAID are the current major donors in the field of microfinance in Egypt, there is a plethora of programs funded through other donors. Economic reform policies in the1990s rendered microfinance an embraced mechanism for poverty alleviation and employment generation. Virtually every donor with a poverty alleviation mandate in Egypt supported or continues to support microfinance programs by providing seed capital, technical support, or research and information dissemination. The list includes, but is not limited to, the Canadian International Development Agency, UNICEF, the Ford Foundation, the National Council of Negro Women, the Egyptian-Swiss Development Fund, Save the Children, the German Agency for Technical Co-operation, the Netherlands Organization for International Development Co-operation, the United Nations Development Program (UNDP), the Friedrich Ebert Foundation, the Italian Fund of Egypt, and more recently the European Commission's MEDA Program (the Euro-Mediterranean Partnership) (Nader, 2016; Amolat, 2014).

The Egyptian business environment offers many entrepreneurial opportunities. Various programs and policies were being put in place by the government to encourage entrepreneurial activities. The extent to which the Egyptian populace has taken advantage of the numerous business opportunities in the country however remains a perturbed issue. This is especially so if one considers the rate of unemployment that keeps increasing over the years in the country. Despite the numerous advantages of being an entrepreneur, an average Egyptian citizen seems to prefer salaried job which has led to high unemployment rate in the country (Agnes, 2015).

Unfortunately, there is uneasy access to the conventional loan from the commercial banks to start up a small or medium scale enterprise. The resultant effect is that the underdevelopment situation of the country is getting worse while government seems incapable of taming the ugly incidence. The symptom of this situation is high poverty rate, high unemployment rate, and economic dependence on foreign countries. Commercial banks usually demand for collateral security before giving out loans for business purposes. This is a necessary factor in obtaining loan as collateral security serves as guarantee for recovering of loans given out by commercial banks in case of repayment default. An average citizen in Egypt cannot provide such collateral security. This results to inability of an average Egyptian to access loans from commercial banks. Thus the difficulty of access loan from financial institutions such as commercial banks constitutes a great setback to entrepreneurial development in Egypt (Morduch, 2012). The evolution of microfinance in the 1970s is to break the barricade to access capitals by low income individuals for developmental purposes. Microfinance is the provision of financial services to lowincome, poor and very poor self-employed people (Otero, 2000). To say that microfinance empowers the entrepreneurial spirits that exist among small-scale entrepreneurs worldwide is not an exaggeration. Microfinance has the ability to strengthen micro enterprises and encourage best practices among operators of small and medium scale enterprise (Anderson, 2013).

Over two and half decades, governments of developing countries have formulated great programs for economic development. One possible explanation for the relative absence of SMEs in the poor economies is the difficulty of obtaining access to finance. Large firms in these countries can secure financial assistance because they have assets that can serve as collaterals for loans (Ashe 2010).

Microfinance has evolved as an economic development approach intended to benefit low income men and women. The term refers to the provision of financial services to low income clients, including the self employed. Financial services generally include savings and credit; however, some microfinance institutions also provide insurance and payment services. 
In addition to financial intermediation, many microfinance institutions provide social intermediation services such as group formation, development of self confidence, and training in financial literacy and management capabilities among members of a group (Chaflin, 2010). Thus, the definition of microfinance also includes both financial intermediations and social intermediations. Microfinance clients are typically self employed, low income entrepreneurs in both urban and rural areas. Clients are often traders, street vendors, small farmers, service providers and artisans and small producers such as blacksmiths and seamstresses. Usually, their activities provide a stable source of income (often from more than one activity). Although they are poor, they are generally not considered to be the poorest of the poor (Ledgerwood, 2011).

\section{Government View of the Microfinance Sector}

It is important to determine the government's position regarding the informal sector and micro enterprise development, as this affect policies that may influence the behavior of micro entrepreneurs. Some governments recognize the positive contribution of micro enterprises to the economy and may actively include informal sector development in the national plan. However in many countries, informal sector issues and their relationship to government issues receive little attention. Most policy framework favour large manufacturing sector and are biased against the informal sector and small enterprises. Most governments want to encourage the development of business in their own countries. Some governments supplement general policy goals that apply to business with specific policies and programs aimed at micro and small enterprises. It is helpful if policies are in places that establish a favorable climate for the start up of small businesses and the growth of existing businesses. Examples are policies that minimize the cost of licensing and registering a business, provide easy access to information about laws and regulations, and facilitate commercial codes. This establishes rules to minimize the cost of doing business by defining the rights and responsibilities of all parties to a transaction. The decision of governments to become actively involved in micro finance development through credit programs or other enterprise development services can affect the environment for private microfinance providers, either by negatively distorting the market or by positively contributing to the supply of services. Alternatively, government can choose to support the informal sector through macro policies, or work with Non Governmental Organizations (NGOs) that provide service and training. Active collaboration in this sense involves the establishment of a favorable climate to enable these institutions to continue and expand their work with support but no interference from government entities. This can include national recognition of the micro enterprise sector, funding research and scaling up pilot programs (Nader, 2016; Druschel, 2013).

Micro enterprises and small business may be affected negatively by government policies through excessive regulations, prohibitive levels of taxation, inadequate government protection against cheap imported products, laxity about black markets (which results in unfair competition for the micro business sector), harassment by government officials for operating businesses on the streets, and inadequate services and high user fee in public market structure. Many of these regulations work effectively to encourage micro enterprises to remain outside the legal or formal mainstream (Engle, 2012).

When policies and practices negatively affect clients businesses, a microfinance institution or donor may choose to undertake environment level interventions, such as policy and advocacy work, in addition to providing or supporting the provision of financial services. Advocacy can include helping clients organize to protest unfair policies or treatment. Microfinance institutions can influence policy by working alone or through coalitions of similar organizations to lobby appropriate government or regulatory bodies on behalf of their clients (Parker, 2006; Rahman, 2015).

\section{Objectives of Micro Finance Institutions}

Selecting a target market depend on the micro service provider and the perceived demand for financial services. In any country, there are underserved enterprises and households, ranging from the ultra poor who may not be economically active, to small growing enterprises that provide employment in their communities. This range constitutes the demand size for micro finance services. Often, the supply side does not offer corresponding continuous services. Microfinance institutions need to supply services that fill the gaps and integrate the underserved group into the market. The goal of microfinance institutions as development organization is to service the financial needs of served and underserved market as a means of meeting development objectives. These development objectives generally include one or more of the following (Sen, 2012; Salib, 2014): 
- To reduce poverty

- To empower women or other disadvantaged population groups

- To create employment

- To help existing business grow or diversify their activities

- To encourage the development of new businesses

In a World Bank (2016) study of lending for SMEs projects, three objectives were most frequently cited, these include:

- To create employment and income opportunities through the creation and expansion of micro enterprises

- To increase the productivity and income of vulnerable groups, especially women and the poor

\section{Research Methodology}

This section focuses on the research techniques adopted and used for this study with the aim of achieving the research objectives. Survey research design is adopted in this study. Survey research design was chosen because the sampled elements and the variables that are being studied are simply being observed as they are without making any attempt to control or manipulate them. Data were collected from a sample of enterprises to determine the relationship between entrepreneurial development (the dependent variable) and microfinance (the independent variable). The theoretical population of the study consists of the entire SMEs in the country.

However, the study was restricted to Greater Cairo. The choice of which stems from the fact that it is the commercial centre of Egypt and the concentration and predominance of SMEs in Greater Cairo are easily identifiable. For effective coverage and lower cost, purposive sampling technique was used to select the participating SMEs. A simple random sampling technique was used to select a total of 60 entrepreneurs that constituted the sample size. It should be pointed out that limited financial resources at the researcher's disposal could not permit or allow for a greater sample size. Primary method of data collection was used in this study. The primary data consists of a number of items in well-structured non-disguised questionnaire that was administered to and completed by the respondents. The decision to structure the questionnaire is predicated on the need to reduce variability in the meanings possessed by the questions as a way of ensuring comparability of responses. The questionnaire is titled "Strategic Impact of Microfinance on Entrepreneurial Development Questionnaire." The return rate of completed questionnaire was 80 percent as we were able to get back 48 out of 60 questionnaires given to our respondents. Thus, only 48 questionnaires were used for final analysis in this study.

To ensure the validity and reliability of the questionnaire used for the study, odd number of experts was consulted to look at the questionnaire items in relation to its ability to achieve the stated objectives of the research, level of coverage, comprehensibility, logicality and suitability for prospective respondents. A pilot test which took the form of test-retest method was conducted prior to the actual study.

Data collected from the questionnaire were analyzed, summarized, and interpreted accordingly with the aid of descriptive statistical techniques such as total score and simple percentage. Chi-square was used to measure the discrepancies existing between the observed and expected frequency and to proof the level of significance in testing stated hypotheses. Regression analysis and Analysis of Variance (ANOVA) were computed with the help of Statistical Packages for Social Sciences (SPSS). The trends, and patterns and relationship among data were identified and interpreted.

\section{Testing of Hypotheses and Interpretation of Results}

Three hypotheses were raised for this study and tested at 0.05 significant levels.

Hypothesis 1: There is no significant difference in the number of entrepreneurs who used Microfinance Institutions and those who do not.

Table 1: $X^{2}$ Summary

\begin{tabular}{|c|c|c|c|c|}
\hline Variable & $\mathrm{N}$ & $\mathrm{DF}$ & $\mathrm{X}^{2}-\mathrm{ob}$ & p-value \\
\hline Adoption of Microfinance Institutions & 38 & \multirow[t]{2}{*}{1} & \multirow[t]{2}{*}{12.44} & \multirow[t]{2}{*}{$<0.05$} \\
\hline Non adoption of Microfinance Institutions & 10 & & & \\
\hline
\end{tabular}

Chi-square allows testing the statistical significance of differences in a classification system (one-way classification) or the relationship between two classification systems (two-way classification). To perform the Chi-square test, the data should be classified in a frequency table (this test is not performed on the raw data). 
A frequency table shows the number of cases that belong simultaneously to two or more distinct categories as presented under " $\mathrm{N}$ " column. In this study adoption and non-adoption of microfinance institutions classification of participants into types of enterprise revealed a significant difference among entrepreneur in the prevalence business and service they engage in at $\mathrm{X}^{2}=12.44,1$ degree of freedom and 0.05 significant level. It implies that most entrepreneurs chose microfinance institutions (38) $79.2 \%$ and non-adoption of microfinance institutions (10) $19.8 \%$. Hypothesis one is rejected.

Hypothesis 2:

There is no significant effect of microfinance institutions' activities in predicting entrepreneurial productivity.

Table 2: Model Summary of the Simple Regression for Entrepreneurial Productivity

\begin{tabular}{|l|l|l|l|l|}
\hline Model & R & R square & Adjusted R square & Std. Error of the Estimate \\
\hline 1 & 0.722 & 0.50 & 0.48 & 128.4227 \\
\hline
\end{tabular}

a. Predictors: (Constant microfinance institutions activities)

To test the second hypothesis, simple regression analysis was used to regress the independent variable against dependent variable used in determining independent variable. Table 2 above indicates the model summary of the simple regression equation that predicted entrepreneurial productivity. The explanation of the values presented is given in the table below.

Table 3: Summary of Analysis of Variance for Entrepreneurial Productivity

\begin{tabular}{|c|c|c|c|c|c|c|}
\hline Model & Variations & $\begin{array}{c}\text { Sum of } \\
\text { Squares }\end{array}$ & Df & $\begin{array}{c}\text { Mean } \\
\text { Square }\end{array}$ & F & Sig. \\
\hline \multirow{2}{*}{1} & Regression & 466 & 1 & 466 & 16.64 & 0.05 \\
\cline { 2 - 6 } & Residual & 1316 & 47 & 28 & & \\
\cline { 2 - 7 } & Total & 1782 & 48 & & & \\
\hline
\end{tabular}

a) Predictors: (Constant microfinance institutions activities)

Source: Field Survey, 2016.

The model summary table provides useful information about the regression analysis. First, the 'multiple R' column is the correlation between the actually observed independent variables and the predicted dependent variable (i.e., predicted by the regression equation). ' $R$ square' is the square of $R$ and is also known as the 'coefficient of determination'. It states the proportion (percentage) of the (sample) variation in the dependent variable that can be attributed to the independent variable(s). In this study, $50 \%$ of the variations in entrepreneurial productivity could be accounted for by the microfinance activities. The 'adjusted R square' refers to the best estimate of R square for the population from which the sample was drawn. Finally, the 'standard error of estimate' indicates that, on average, observed entrepreneurial productivity deviate from the predicted regression line by a score of 128.4227 . The hypothesis two which stated that" there is no significant effect of microfinance institutions activities in predicting entrepreneurial productivity was rejected at $\mathrm{R}=.722, \mathrm{R}^{2}=.50, \mathrm{~F}(1$, 48) $=.16 .64 ; \mathrm{p}<.05$. This implies that there is a significant effect of microfinance institutions activities in predicting entrepreneurial productivity.

Hypothesis 3:

There is no significant effect of microfinance institutions activities in predicting entrepreneurial development.

Table 4: Model Summary of the Simple Regression for Entrepreneurial Development

\begin{tabular}{|c|c|c|c|c|}
\hline Model & $\mathrm{R}$ & $\mathrm{R}$ square & Adjusted R square & Std. Error of the Estimate \\
\hline 1 & 0.462 & 0.213 & 0.189 & 2.1427 \\
\hline
\end{tabular}

a) Predictors: (Constant microfinance institutions activities)

Source: Field Survey, 2016.

To test the third hypothesis, simple regression analysis was used to regress the independent variable against dependent variable used in determining independent variable. Table 4 above indicates the model summary of the simple regression equation that predicted entrepreneurial development. The explanation of the values presented is given in table 5 below. 
Table 5: Summary of Analysis of Variance for Entrepreneurial Development

\begin{tabular}{|c|l|l|c|c|c|c|}
\hline Model & Variations & Sum of Squares & Df & Mean Square & F & Sig. \\
\hline \multirow{3}{*}{1} & Regression & 1127.28 & 1 & 1127.28 & 20.13 & 0.05 \\
\cline { 2 - 5 } & Residual & 26.32 & 47 & 56 & & \\
\cline { 2 - 4 } & Total & 3759.28 & 48 & & & \\
\hline
\end{tabular}

a) Predictors: (Constant microfinance institutions activities)

Source: Field Survey, 2016.

The model summary table provides useful information about the regression analysis. First, the 'multiple R' column is the correlation between the actually observed independent variables and the predicted dependent variable (i.e., predicted by the regression equation). ' $R$ square' is the square of $R$ and is also known as the 'coefficient of determination'. It states the proportion (percentage) of the (sample) variation in the dependent variable that can be attributed to the independent variable(s). In this study, $21 \%$ of the variations in entrepreneurial development could be accounted for by the microfinance activities. The 'adjusted R square' refers to the best estimate of R square for the population from which the sample was drawn. Finally, the 'standard error of estimate' indicates that, on average, observed entrepreneurial development deviate from the predicted regression line by a score of 2.1427 . The hypothesis three which stated that" there is no significant effect of microfinance institutions activities in predicting entrepreneurial development was rejected at $\mathrm{R}=.462, \mathrm{R}^{2}=.213, \mathrm{~F}$ $(1,48)=20.13 ; \mathrm{p}<.05$. This implies that there is a significant effect of microfinance institutions activities in predicting entrepreneurial development.

\section{Summary of Research Findings}

This research work has been able to identify the impact of microfinance on entrepreneurial development in Egypt. The analysis of data indicates that financial institutions are not adequately financing SMEs.

The findings are as follows:

- There is a significant difference in the number of entrepreneurs who used Microfinance Institutions and those who do not.

-There is a significant effect of microfinance institutions activities in predicting entrepreneurial productivity.

- There is no significant effect of microfinance institutions activities in predicting entrepreneurial development.

- Microfinance is sustainable to the development of entrepreneurship activities in Egypt.

- People have access to capital for entrepreneurship development in Egypt through microfinance.

- Microfinance has affected entrepreneurship in the country positively.

- Entrepreneurship development is vital to the industrialization process of the country.

The major contribution of microfinance institutions to the developing economy like that of Egypt is its role in promoting entrepreneurship development in the nation. One of the goals of entrepreneurship routed by successful Egyptian government has been the reduction of unemployment and poverty alleviation. A cordial thrust in public policy for the achievement of indigenous entrepreneurship through the provision of long term loans and equity capital by banks for enterprise. Given the gap between savings and invertible funds, the short fall is provided by credit delivery. Many newly developed and developing countries have therefore made credit delivery an endurable strategy in the development of entrepreneurship in both industry and agriculture.

\section{Conclusions and implications}

The review of several literature shows that the microfinance institutions are evident tools for entrepreneurship development due to the various services they offer and the role they performs towards the development of the economy. Not overlooking the various challenges that affect microfinance operations.

Microfinance institutions world over and especially Egypt are identified to be one of the keys players in the financial industry that have positively affected individuals, business organizations, other financial institutions, the government and the economy at large through the services they offer and the functions they perform in the economy. Microfinance institutions have positive relationship with the Egyptian economy represented by expanded GDP. Although, interest rate is not significantly influential, the results of findings of this study can still be summarized that the microfinance institutions and their activities go a long way in the determination of the pattern and level of economic activities and development in the Egyptian economy. 


\section{References}

Agnes, Y (2015). “Engendering Microfinance Services: Beyond Access.” Paper presented at the Women's Empowerment or Feminisation of Debt? Workshop, London, March.

Amin, S., Rai, A. S., Topa, G., (2010). "Does Microcredit Reach the Poor and Vulnerable? Evidence from Northern Bangladesh", Journal of Development Economics, 70(1), 59-82.

Amolat, F. R. (2014) Client Impact Assessment: KMBI Program Impact Assessment for Microfinance Implementation for Region 1.

Anderson, L., Locker, L., Nugent, R., (2013), Microcredit, Social Capital, and Common Pool Resources, World Development, Vol.30, No.1, 95-105.

Ashe, J., and Lisa P. (2010). Impact Evaluation of PACT's Women's Empowerment Program in Nepal: A Savings and Literacy Led Alternative to Financial Institution Building. Cambridge, Mass.: Brandeis University.

Barsoum, G., (2013). Who gets credit? The Gendered Division of Microfinance Programs in Egypt, Canadian Journal of Development Studies.

Chalfin, B. (2010). "Risky Business: Economic Uncertainty, Market Reforms and Female Livelihoods in Northeast Ghana." Development and Change. Vol, 2. No. 31. pp. 987-1008.

Copestake, J. B., Halotra, S., Johnson, S., (2010). "Assessing the Impact of Microcredit: A Zambia Case Study", Journal of Development Studies, 37(4), 81-100.

Druschel, K. (2013). "State of the Microcredit Summit Campaign Report." Washington, D.C.: Microcredit Summit Campaign Secretariat.

Engle, P. (2012). "Father's Money, Mother's Money, and Parental Commitment: Guatemala and Nicaragua." In Engendering Wealth and Well-Being: Empowerment for Global Change. Ed. RaeLesser Blumberg et al. Boulder, Colo.: Westview Press. 20

Evans, T. G., Adams, A. M., (2009). "Demystifying Non Participation in Microcredit: A Population-Base Analysis", World Development, 27(2), 419- 430.

Fasua, K. O., (2014). Entrepreneurship Theory, Strategy and Practice. Abuja, Bee Printing \& Publishing CO.

Ledgerwood, J., (2011). Sustainable Banking for the Poor Project. (World Bank) South Asia.

Morduch, J., (2012) “The Microfinance Promise", Journal of Economic Literature, Vol. 37, No.4, p 319.

Nader, Y., (2016). Microcredit and the socio-economic wellbeing of women and their families in Cairo. The Journal of Socio-economics 37 (2008) 644-656. no. 1. pp: 45-63.

Otero, M., (2000). Bringing Development Back into Microfinance, ACCION International.

Park, A., (2001) "Microfinance with Chinese Characteristics", World Development, 29, (1), 39-62.

Parker, S. C., (2006). The Economics of Entrepreneurship, London, Edward Edgar Publishing Ltd.

Rahman, A. (2015). "Micro-credit Initiatives for Equitable and Sustainable Development: Who Pays?" World Development 27, no. 1. pp: 67-82.

Ryne, E., Holt, S., (2000). Women in Financial and Entrepreneurial Development, Education \& Social Policy. Washington, D. C., Discussion Paper 40, World Bank.

Salib, S., (2014). FORA's Impact among Migrants: Primary Findings. Oak Brook, Ill.: Opportunity International Network. Vol. 3, pp. 56-82.

Sen, G. (2012). "Engendering Poverty Alleviation: Challenges and Opportunities.”Development and Change. Vo. 2. No. 30. pp: 685-92.

USAID (2013). Microenterprise Development in a Changing World: U.S. Agency for International Development Microenterprise Results Reporting for 2000. Arlington, Va.: Weidemann Associates.

World Bank (2016).A Better Investment Climate for Everyone. World Development Report. Washington, DC: World Bank. 